\title{
INTEGRATING MULTI-RECEIVER EMI MEASUREMENTS TO CHARACTERIZE THE SOIL-LANDSCAPE AROUND THE SCHOOL OF GLADIATORS, CARNUNTUM
}

\author{
T. Saey, M. Van Meirvenne, I. Trinks, P. De Smedt, G. Verhoeven, W. Neubauer
}

\begin{abstract}
Recently, the foundations of a school of gladiators were discovered by employing a combination of non-invasive prospection techniques in the Roman town of Carnuntum, $40 \mathrm{~km}$ south-east of Vienna (Austria). Although the well-preserved remains of the school were revealed using high-resolution geophysics, some questions about the surrounding soil landscape remained unanswered. Therefore, a proximal soil sensing procedure based on a single electromagnetic induction (EMI) survey with a multireceiver EMI instrument was applied to map the school of gladiators and its surroundings covering a 5.6 ha area. We investigated both the complementarity of the apparent electrical conductivity (ECa) and apparent magnetic susceptibility (MSa) measurements for mapping the school and its soil landscape. As a result, an integrated visualisation of the school in its soil landscape was obtained. This study proved the huge potential of EMI soil sensing to interpret the soil landscape and to discern smallscale natural and archaeological features without any invasive practice.
\end{abstract}

\section{INTRODUCTION}

Over the past years, the use of geophysical methods in geoarchaeological studies have increased substantially (Brown, 2008; Van Dam, 2012). In such studies, magnetometry and ground penetrating radar (GPR) were used most frequently (Gaffney and Gater, 2003). Much less common is the use of low frequency electromagnetic induction (EMI) methods. However, the latter is commonly deployed in proximal soil sensing and precision agriculture because measurements of the apparent electrical conductivity (ECa) allow the detailed characterization of the variability of soil properties such as texture, organic matter and moisture (Domsch and Giebel, 2004; Heil and Schmidhalter, 2012; McBratney et al., 2005; Saey et al., 2009b). Besides ECa, EMI methods measure simultaneously the apparent magnetic susceptibility (MSa) (Simpson et al., 2010). The MSa provides additional information compared to measurements with a magnetometer.

To enlarge their applicability, some EMI instruments have multiple receiver coils creating a potential for depth investigations of the electrically conductive and magnetic features (Saey et al., 2012). When such information is available over a larger area, the detailed reconstruction of the soil-landscape becomes possible, e.g. Saey et al. (2011) and De Smedt et al. (2012). Such information is highly complementary to the understanding of buried archaeological structures revealed with other methods (e.g. De Clercq et al., 2012).

Recently, the Ludwig Boltzmann Institute for Archaeological Prospection and Virtual Archaeology (LBI ArchPro) announced the discovery of the buried remains of a gladiator school (a "ludus gladiatorius") next to the excavated amphitheatre of the Roman city of Carnuntum, Austria. This was achieved by combining high-resolution magnetometry and multi-antennae GPR measurements (Neubauer et al., 2011). However, these methods did not provide information about the composition of the soil and its variability. The aim of this research is to evaluate the usefulness of an EMI survey with a multi-receiver instrument, registering simultaneously ECa and MSa, to characterize the soil variability around the gladiator school. We will especially focus on the ability to interpret the soil-landscape of this highly valuable archaeological site.

\section{ROMAN CITY OF CARNUNTUM AND STUDY AREA}

The city of Carnuntum was located some $40 \mathrm{~km}$ south-east of Vienna on the south bank of the Danube (Figure 1). As the capital of the Roman province Pannonia, it was home to an estimated 50,000 inhabitants between the 2 nd and 4 th centuries AD. Outside its gates, this city possessed one of the largest amphitheatres of the Roman Empire. After the invasion by the German tribes, the city was completely destroyed and today only the remains of one gate survive above ground (Neubauer et al., 2002). In the beginning of the 20th century, the amphitheatre was discovered, and its foundations were excavated between 1923 and 1930. Recently the LBI discovered the buried remains of the school of gladiators in an adjacent field using several non-invasive techniques (Figure 1) (Trinks et al., 2010). Because the buried remains of the entire Roman town and surroundings are currently protected, no destructive prospection techniques are still allowed. Our study site represents a 5.6 ha arable field, containing the gladiator school and bordering the excavated amphitheatre (Figure 1).

Our study site is located on slightly undulating, fluviatile and gravel-rich terraces of the nearby river Danube. Near the end of the Weichselian glacial period, this area was covered by aeolian loess deposits from a variable but generally limited thickness. The study area has a slightly undulating topography with a range in elevation of $12.9 \mathrm{~m}$. In general it slopes to the northwest.

\section{SOIL SENSOR SURVEY}

The study area was investigated with an EMI sensor with one transmitter coil and four receiver coils, the DUALEM-21S instrument (DUALEM, Milton, Canada) (Saey et al., 2009a). Both transmitter-receiver spacing and orientation determine the depth and weighting response pattern of the signal. This multi-receiver EMI instrument allows measuring both the ECa and MSa of four different soil volumes.

In our mobile configuration, thee sensor was put in a nonmetal sled and pulled behind an all-terrain vehicle at a speed of about $6-10 \mathrm{~km} \mathrm{~h}^{-1}$, crossing the field at parallel lines $0.85 \mathrm{~m}$ apart. The eight simultaneous ECa measurements were recorded by a field computer at a frequency of about $8 \mathrm{~Hz}$ and connected to a DGPS. Within lines, measurement intervals were at about $0.1 \mathrm{~m}$. 


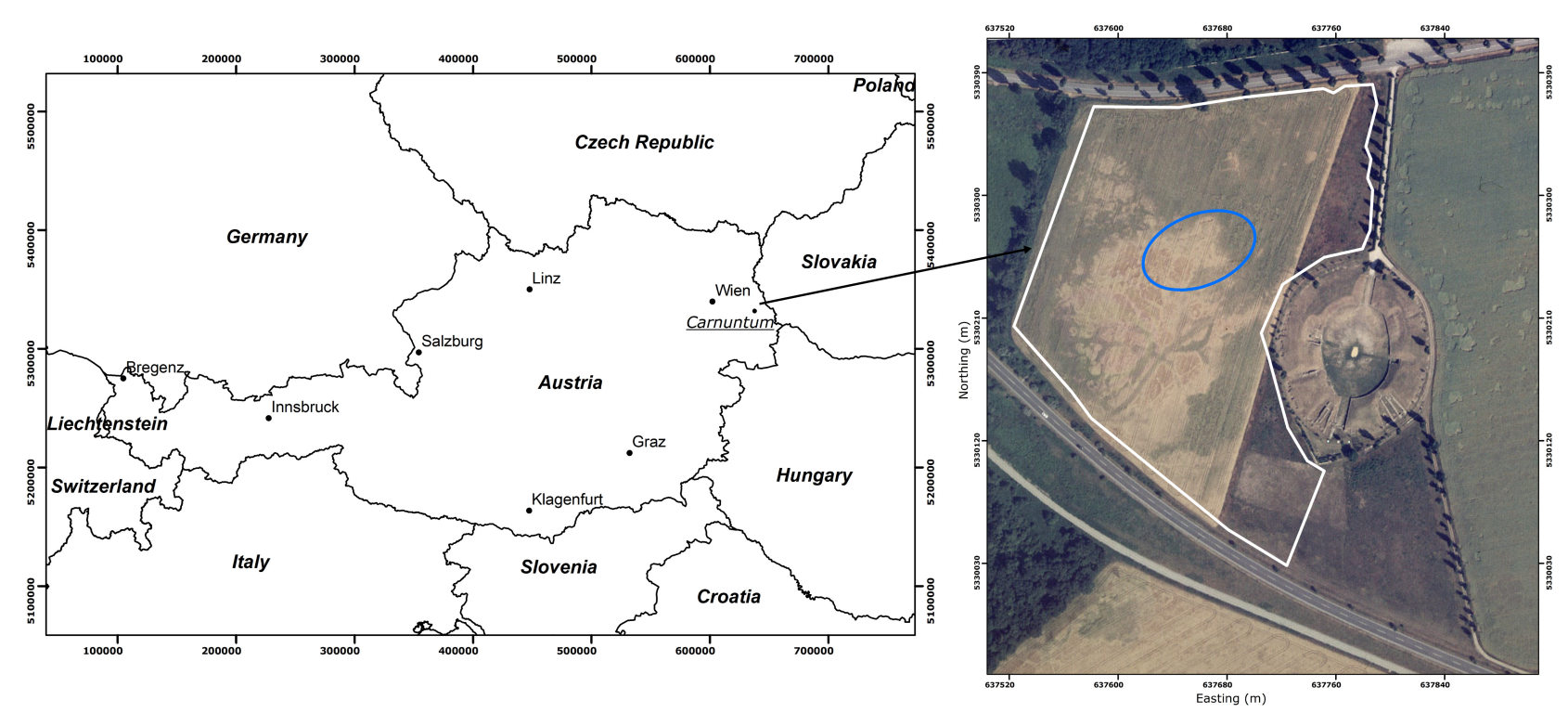

Figure 1: Localisation of the study site in Austria and aerial photograph with indication of the study site (red) and the position of the school of gladiators (oval).

\section{ECA AND MSA SURVEY}

The mean ECa increases from the shallowest to the deepest measuring coil configurations, indicating that the subsoil is on average much more conductive than the topsoil. In this case the increase is rather strong and it most likely indicates also an average increase in clay content with increasing depth.

The MSa measurements depict a general magnetic variation across the study area with strong contrasts between the northeastern part and the southern and eastern parts. These maps reveal the archaeological structures related to the school of gladiators. A curved structure, crossing the area from the southwest to the northeast, is visible on all four MSa maps. This structure is known to the archaeologists of the LBI as one of the major water delivery canals (aqueduct) to the city of Carnuntum.

\section{DEPTH SLICING}

The modelled conductivity (EC) or modelled magnetic susceptibility (MS) of a particular depth interval or slice can be deduced from integrating the measured ECa or MSa values. The major advantage of isolating the contribution to EC or MS of a particular depth slice is that its interpretation can be linked to a particular depth.

On the study site, the EC-depth slicing resulted in an enhanced visibility of patterns. In the north-western part of the study site, a fine-scale polygonal network appears. Based on previous experience with EMI sensors we interpreted this network as frost-wedge pseudomorphs (Cockx et al., 2006; Meerschman et al., 2011). In the central and northeastern parts of the study area, traces of surface drainage patterns are clearly visible. Most of these gullies flow into the lower part of the area where the frost-wedge pseudomorphs are present. Complementary to the EC-depth slices, MS-depth slicing enhances the visibility of the archaeological traces related to the school of gladiators and its associated structures. The school itself, an outside training area for horses and grave monuments are easily noticeable after depth slicing. When EC and MS data are combined, it becomes clear that the school was constructed on an area with low EC values and outside the area affected by erosion. The builders of the school obviously selected a location near to the amphitheatre, which was situated at a higher position in the landscape with stable (gravel rich) subsoil, avoiding sloping and wet clay rich parts of the area.

\section{CONCLUSIONS}

The potential of multi-receiver EMI for soil-landscape research around archaeological sites is in the ability to integrate the multiple complementary signals of both the electrical conductivity and magnetic susceptibility. Combining the multiple ECa measurements allowed us to interpret the soil landscape. Moreover, the complementary MSa measurements enabled locating the buried archaeological remains.

\section{REFERENCES}

BROWN AG. 2008. Geoarchaeology, the four dimensional (4D) fluvial matrix and climatic causality. Geomorphology 1-2: 278-297. Cockx L, Ghysels G, Van Meirvenne M, Heyse I. 2006. Prospecting frost-wedge pseudomorphs and their polygonal outline using electromagnetic induction. Permafrost and Periglacial Processes 17: 163-168.

De Clerce W, De Smedt P, De Reu J, Herremans D, Masters P, Saey T, Stichelbaut B, Van Meirvenne M. 2012. Towards an integrated methodology for assessing rural settlement landscapes in the Belgian lowlands. Archaeological Prospection 19: 141-145.

De Smedt P, Van Meirvenne M, Davies nS, Bats M, Saey T, De Reu J, Meerschman E, Gelorini V, Zwertvaegher A, Antrop M, Bourgeois J, De Maeyer P, Finke PA, Verniers J, CROMbé P. 2012. A multidisciplinary approach to reconstructing Late Glacial and Early Holocene landscapes. Journal of Archaeological Science, in press.

Domsch H, Giebel A. 2004. Estimation of soil textural features from soil electrical conductivity recorded using the 
EM38. Precision Agriculture 5: 389-409.

GAFFney C, GATER J. 2003. Revealing the buried past: Geophysics for archaeologists. Tempus Publishing: Stroud.

Heil K, Schmidhalter U. 2012. Characterisation of soil texture variability using the apparent electrical conductivity at a highly variable site. Computers \& Geoscience 39: 98-110.

Meerschman E, Van Meirvenne M, De Smedt P, Saey T, Islam MM, Meeuws F, Van De ViJVer E, Ghysels G. 2011. Imaging a Polygonal Network of Ice-Wedge Casts with an Electromagnetic Induction. Soil Science Society of America Journal 75: 1-6.

McBratney A, Minasny B, Whelan BM. 2005. Obtaining 'useful' high-resolution soil data from proximally-sensed electrical conductivity/resistivity (PSEC/R) surveys. In Precision agriculture '05,: Stafford JV (ed.).Wageningen Academic Publishers: Wageningen; 503-510.

Neubauer W, Eder-Hinterleitner A, Seren S, Melichar P. 2002. Georadar in the Roman civil town Carnuntum, Austria: an approach for archaeological interpretation of GPR data. Archaeological Prospection 9: 135-156.

Neubauer W, Doneus M, Trinks I, Verhoeven G, HinterleitNer A, SEREN S, LÖCKER K. 2011. Long-term integrated archaeological prospection at the Roman Town of Carnuntum/Austria. Laurence Seminar Publication. Cambridge, in press.

Saey T, De Smedt P, Meerschman E, Islam MM, Meeuws F, Van De Vijver E, Lehouck A, Van MeirVENNE M. 2012. Electrical conductivity depth modelling with a multireceiver EMI sensor for prospecting archaeological features. Archaeological Prospection 19: 21-30.

SAey T, Simpson D, VermeErsch H, CockX L, VAN
MeIRVEnne M. 2009a. Comparing the EM38DD and DUALEM-21S Sensors for Depth-to-Clay Mapping. Soil Science Society of America Journal 73: 7-12.

Saey T, Van Meirvenne M, Vermeersch H, Ameloot N, CockX L. 2009B. A pedotransfer function to evaluate the soil profile textural heterogeneity using proximally sensed apparent electrical conductivity. Geoderma 150: 389-395.

Saey T, Van Meirvenne M, De Smedt P, Cockx L, Meerschman E, Islam MM, Meeuws F. 2011. Mapping depth-to-clay using fitted multiple depth response curves of a proximal EMI sensor. Geoderma 162: 151-158.

Simpson D, VAN MeIRVEnNe M, LÜCK E, RÜHLManN J, SAey T, Bourgeois J. 2010. Sensitivity of multi-coil frequency domain electromagnetic induction sensors to map soil magnetic susceptibility. European Journal of Soil Science 61: 469-478.

TABBAGH A. 1986. What is the best coil orientation in the Slingram electromagnetic prospecting method? Archaeometry 28: $185-196$.

Thiesson J, Dabas M, Flageul S. 2009. Detection of resistive features using towed Slingram electromagnetic induction instruments. Archaeological Prospection 16: 103-109.

TRINKS I, JOHANSSON B, GUSTAFSSON J, EMILSSON J, Friborg J, Gustafsson C, Nissen J, Hinterleitner A. 2010. Efficient, large-scale archaeological prospection using a true three-dimensional ground-penetrating radar array system. Archaeological Prospection 17: 175-186. doi 10.1002/arp.381.

VAN DAM RL. 2012. Landform characterization using geophysics - Recent advances, applications, and emerging tools. Geomorphology 137: 57-73. 